\title{
Effect of listeriolysin O (LLO) secreted by listeria monocytogenes on apoptosis of macrophages derived from patients with macrophage activation syndrome- in vitro
}

\author{
Reza Shiari ${ }^{1 *}$, Negin Kohkar ${ }^{1}$, Abdollah Karimi ${ }^{2}$, Sudabeh Taheri ${ }^{3}$ \\ From 21st European Pediatric Rheumatology (PReS) Congress \\ Belgrade, Serbia. 17-21 September 2014
}

\section{Introduction}

The term of macrophage activation syndrome (MAS) refers to a condition caused by excessive activation and expansion of $\mathrm{T}$ lymphocytes and macrophagic histiocytes that exhibit hemophagocytic activity. The expansion of these cells also leads to a massive systemic inflammatory response associated with pan cytopenia, liver dysfunction, and coagulopathy consistent by disseminated intravascular coagulation (DIC).

MAS has been reported in association with almost any rheumatic disease and most common in systemic onset JIA. However, the pathological mechanisms of MAS are not fully understood.

\section{Objectives}

In clinically similar primary HLH, the uncontrolled proliferation of $\mathrm{T}$ cells and macrophages has been linked to decreased natural killer (NK) cell and cytotoxic T cell function, often due to mutations in the gene encoding perforin. Deficient cytotoxic function lead to Inefficient apoptosis and overactivated macrophages.

Because high doses of LLO are known to cause cell death by necrosis or apoptosis, we decided to evaluate the effect of LLO on apoptosis of macrophages derived from patients with macrophagea ctivation syndrome- In vitro.

\section{Methods}

Blood from MAS patients and healthy donors was collected in Falcon tubes containing EDTA at $2 \mathrm{mM}$ final concentration and incubated with enrichment antibody

Pediatric Rheumatology, Shahid Beheshti University of Medical Sciences,

Tehran, Iran, Islamic Republic Of

Full list of author information is available at the end of the article cocktail ( $50 \mu \mathrm{l}$ per $\mathrm{ml}$ of whole blood) at room temperature for 20 minutes. Cells were then separated by density gradient using Ficoll-Paque ${ }^{\mathrm{TM}}$ PLUS (GE Healthcare). Platelets present in the enriched monocyte fraction were discarded by 3 washing steps in PBS, 2\% FBS. Finally, monocytes were seeded in RPMI 10\% FBS, $4 \mathrm{mM}$ L-Glutamine with Pen/Strep at a concentration of $5 \times 10^{5}$ cells $/ \mathrm{ml}$ in 12-well tissue culture treated plates for 6 days. The effects of various concentration of LLO ( $10 \%, 25 \%$, $50 \%, 75 \%$ and more) were evaluated on apoptosis of macrophages in both groups.

\section{Results}

By using LLO less than $75 \%$, there were no apoptosis in both normal and patients groups. However, $50 \%$ of macrophages of healthy donors and $82 \%$ of MAS patients showed apoptosis by LLO 75\% and more.

\section{Conclusion}

High concentrated LLO may induce significant apoptosis in macrophages derived from patients with Macrophage Activation syndrome- In vitro.

\section{Disclosure of interest}

None declared.

\section{Authors' details}

${ }^{1}$ Pediatric Rheumatology, Shahid Beheshti University of Medical Sciences, Tehran, Iran, Islamic Republic Of. ${ }^{2}$ PIRC, Shahid Beheshti University of Medical Sciences, Tehran, Iran, Islamic Republic Of. ${ }^{3}$ Immunology, Shahid Beheshti University of Medical Sciences, Tehran, Iran, Islamic Republic Of. 
Submit your next manuscript to BioMed Central and take full advantage of:

- Convenient online submission

- Thorough peer review

- No space constraints or color figure charges

- Immediate publication on acceptance

- Inclusion in PubMed, CAS, Scopus and Google Scholar

- Research which is freely available for redistribution

Submit your manuscript at www.biomedcentral.com/submit
C Biomed Central 